\title{
Right Brain-to-Right Brain Psychotherapy: Recent Clinical and Scientific Advances*
}

\begin{abstract}
Allan Schore**
In my ongoing studies I continue to suggest that the mental health field is currently experiencing a paradigm shift, in large part due to the integration of neuroscience within updated models of clinical treatment (see Schore, 2003b, 2012, 2019a). Indeed, neuroscience as a whole is now in a rapid period of growth, due both to advances in technology and to its expanding connections with other scientific and clinical disciplines. This expansion is being fueled by the rediscovery of brain lateralization, first established in the nineteenth century at the dawn of modern neurology, and the recent discoveries of the different structural and functional organizations of the right and left brains, the unconscious and conscious minds. My clinical and theoretical models represent ongoing investigations of the right brain and its adaptive bodily-based emotional, relational, and survival processes.

With respect to the origins of these two lateralized self systems a large body of research indicates an earlier maturation of the emotional imagistic right brain than the analytic linguistic left brain (see Schore, 1994, 2012, 2003a,b, 2019a,b). Clinical and neuropsychoanalytic studies support Sigmund Freud's (1923) classic formulation that the unconscious mind develops before the conscious mind, and that "thinking in pictures...approximates more closely to unconscious processes than does thinking in words, and it is unquestionably older than the latter both
\end{abstract}

* This article was contributed by Dr. Shore, A.

** UCLA David Geffen School of Medicine 
Journal of Symbols \& Sandplay Therapy, Vol.12 No.2.

ontogenetically and phylogenetically" (p. 21). Consonant with this conceptualization, in his wide ranging studies of the unique specializations of the dual brain hemispheres the neuropsychiatrist Iain McGilchrist (2015) now asserts that "The right hemisphere both grounds our experience of the world at the bottom end, so to speak, and makes sense of it, at the top end," that this hemisphere is more in touch with both affect and the body, and that "neurological evidence supports what is called the primacy of affect and the primacy of unconscious over conscious will" (p. 44).

For the past three decades I have offered interdisciplinary research and clinical data demonstrating that the right brain is the psychobiological substrate of the human unconscious. This right-lateralized deep core of the subjective self evolves in the early mother-infant attachment relationship, and over the lifespan this dynamic system, at levels beneath conscious awareness, intersubjectively communicates with other right brains, that are tuned to receive these communications. This nonverbal communication system lies at the foundation of the evolutionary mechanism of attachment, expressed as the implicit (unconscious) interactive regulation of emotion, and thereby the regulation of biological synchronicity between and within organisms. Thus synchronized right brain-to-right brain affectively charged attachment dynamics act as a biopsychosocial mechanism by which humans are sociophysiologically connected to others in order to co-regulate their internal homeostatic states (Schore, 2003a).

Applying this developmental model of the mother-infant dyad to the clinical context I have described how the co-created psychotherapeutic relationship acts as a dynamic intersubjective context of rapid communications of emotional states within the evolving therapeutic alliance. These spontaneous right brain-to-right brain nonverbal communications of self-states take place in the present moment, a time frame of fractions of a second to 2 to 3 seconds. Importantly, this "relational unconscious" not only communicates with but also synchronizes and is expanded by another relational unconscious (Schore, 2019a, b; 2020a,b). This synchronized coupling of right brain patterns allows the therapeutic dyad to mutually share unconscious implicit communicative, emotional, and regulatory functions, thereby facilitating psychotherapeutic growth and development of the patient's right brain.

In my two recent volumes Right Brain Psychotherapy and The Development of the Unconscious Mind I continue to expand my theoretical and clinical studies of regulation theory, a theory of the development, psychopathogenesis, and treatment of the subjective self. This 
interpersonal neuropsychoanalytic model describes the essential hidden intersubjective context, the process dimension of psychotherapy. Towards that end I offer both scientific and clinical data indicating that recent discoveries in the interpersonal neurobiology are directly relevant to a more complex understanding of the underlying mechanisms of therapeutic action in all forms of psychotherapy (Schore, 2019a,b). In these volumes I describe the essential interpersonal functions of spontaneous nonconscious right brain-to-right brain communications beneath the words of the patient and clinician, and of rapid nonverbal regulatory communications embedded in implicit intersubjective relational processes. Special attention is focused on reenactments of early attachment dynamics and on the growth-facilitating effects of mutual regressions in heightened affective moments of the treatment. Citing extensive clinical material I suggest that psychotherapeutic reen-actments and mutual regressions shed direct light upon the essential dynamic functions of the deepest hidden levels of the unconscious mind, which Freud demonstrated to be centrally involved in all aspects of the human experience.

This "two-person" interpersonal neurobiological model highlights the ongoing neuroplastic development of the right brain as a primary mechanism of change in all forms of psychotherapy, including adult, child, couples, and group psychotherapy. In a recent Special Issue of the journal Psychotherapy entitled "Evidence-based psychotherapy relationships," the editors Norcross and Lambert (2018) assert, "decades of research evidence and clinical experience converge: the psychotherapy relationship makes substantial and consistent contributions to outcome independent of the treatment" (p. 313 my italics). I also offer information about very recent advances in neuroscience methodology and technology that allows for a deeper understanding of the interactions of two right brain systems in the therapeutic relationship co-constructed by the clinician and the patient. The right brain-to-right brain model, first proposed in 1994, is now directly supported in groundbreaking paradigm shifting hyperscanning research of both the patient's and therapist's interacting brains, showing a right-lateralized interbrain synchronization between them during an emotionally-focused psychotherapy session (Zhang et al., 2018, 2020). These advances provide a valuable opportunity for a deeper understanding of the implicit relational processes that operate between both members of the therapeutic dyad at levels beneath conscious awareness.

With respect to this "hidden" unconscious nonverbal attachment bond of emotional communication embedded in the co-created patient-therapist relationship, my ongoing work 
Journal of Symbols \& Sandplay Therapy, Vol.12 No.2.

describes how the rapid, dynamically fluctuating moment-to-moment state-sharing between the patient and the empathic therapist represents an organized dialogue, a nonverbal turn taking conversation occurring within milliseconds. In this interactive matrix both partners spontaneously match states and then simultaneously adjust their social attention, stimulation, and subjective arousal in response to their partner's signals (Schore, 2003b). It is this right brain-to-right brain state sharing that allows each person's conscious and especially unconscious states of mind to be known to the other implicitly (Schore, 2019a,b; 2021a,b).

More specifically, at levels beneath conscious awareness the psychobiologically attuned, intuitive clinician, from the first point of contact, is learning the nonverbal moment-to-moment rhythmic structures of the patient's internal states, and is relatively flexibly and fluidly modifying her own behavior to synchronize with that structure, thereby co-creating a context for the organization of a therapeutic alliance. Note that this right-lateralized interbrain synchronization allows for the dyadic emergence of a right brain-to-right brain communication system. Neuroscience authors are now describing "a form of therapeutic conversation that can be conceived $\cdots$ as a dynamic interplay between right hemispheres" (Meares, 2017), and asserting "The right hemisphere, in fact, truly interprets the mental state not only of its own brain, but the brains (and minds) of others" (Keenan et al., 2005, p. 702).

In such nonconscious moment-to-moment bodily-based communications the sensitive, intuitive therapist can subjectively attend to "barely perceptible cues that signal a change of state" in both the patient and herself, and to intersubjectively detect the patient's "nonverbal behaviors and shifts in affects." This right brain state sharing in turn allows the therapist in a state of therapeutic presence to enter into the patient's changing feeling state, in order to "follow the affect" (Schore, 1994) and to act as an implicit affect regulator of the patient's emotional states. Psychotherapeutic synchronized and interactively regulated right-lateralized communications facilitate neuroplastic structural changes in the patient's right brain regulatory systems, which in turn allow for optimal treatment outcomes in both symptom-reducing and growth-promoting psychotherapies.

My work describes attachment dynamics in secure as well as insecure early attachments, including histories of disorganized-disoriented insecure attachment associated with abuse and neglect. Utilizing a neuropsychoanalytic perspective I continue to describe the underlying implicit neurobiological mechanisms of the right brain in affective communications of regulated and 
dysregulated attachment dynamics, stressful transference-countertransference transactions, and implicit interactive affect regulation, which all operate at levels beneath conscious awareness (Schore, 1994, 2003b, 2012, 2019a). My work specifically focuses on the enduring negative impacts of what I have termed developmental "relational trauma" (Schore, 2001) on the individual's right-lateralized subjective selfs capacity for communicating with other minds, that is, intersubjectivity, as well as for attachment, the interactive regulation of emotion. This relational trauma is associated with the affect blunting defense of dissociation.

In this work conscious and especially unconscious dysregulating experiences are communicated within the emotional attachment bond co-created between patient and therapist on a millisecond time scale, right brain-to-right brain, especially in moments of affective shifts into and out of stressful dysregulated subjective emotional states. These transferential relational stressors of the emotional bond embedded in therapeutic alliance are an essential element in dyadic rupture and repair transactions, a central relational mechanism of the treatment. In rupture-repair these affective transactions can be interpersonally synchronized and interactively regulated, re-establishing the right brain-to-right brain affective bond between two right brains. Over time this interpersonal emotional communication system allows the evolving therapeutic relationship to generate increasing levels of safety and trust, and thereby jointly process reenactments of early developmental stress-related attachment dynamics.

In addition to the attachment mechanism, stressful transference-countertransference communications of early developmental trauma, and clinical enactments of ruptures of the attachment bond, the clinical construct of mutual regression acts as a core mechanism that promotes emotional growth and development in psychotherapy, especially in psychodynamic psychotherapy. In order for this to be achieved there needs to be a mechanism that can transiently shift hemispheric dominance from the therapist's left brain into his or her right brain, the repository of the patient's emotionally stressful and painful autobiographical attachment memoires. A long tradition in the neurological sciences has defined regression as a "taking off of the higher" and "at the very same time a letting go, or expression of the "lower" (Schore, 2019a). From a neuropsychoanalytic perspective the mechanism of regression from the "higher" left into the "lower" right hemisphere, acting at rapid and thereby unconscious levels, provides transient shifts in brain laterality (Schore, 2019a, 2021a). In such the empathic therapist's right brain can receive and respond to the patient's right brain's conscious 
Journal of Symbols \& Sandplay Therapy, Vol.12 No.2.

and especially unconscious early attachment communications. Early in the last century Carl Jung (1912) described the importance of supporting the patient's therapeutic regressions back to earliest stages of life to make contact with a vital generative core of the self that was hidden in the unconscious, the "lost heart to the self:" He stated, "Therapy must support the regression, and continue to do so until the 'prenatal' stage is reached. . . Hence the regression leads back only apparently to the mother . . . but goes back beyond her to the prenatal realm . . . [to] the germ of wholeness. ... It is [the] inherent possibilities of "spiritual" or "symbolic" life and of progress which form the ultimate, though unconscious goal of regression." (paragraphs 508-510).

In light of the current two-person relational model the construct of regression is now being transformed from an intrapsychic regression within one brain to an interpersonal mutual regression shared by two interacting brains. In this manner the patient-therapist therapeutic dyad can access an interpersonal synchronization mechanism that can transiently induce a callosal reversible dominance of the hemispheres in both patient and therapist, from the verbal and cognitive functions of their later-developing "higher" left hemisphere to the nonverbal and social-emotional functions of their early developing "lower" right hemisphere. This spontaneous synchronized state shift of a mutual regression allows the therapeutic dyad to transition from "top-down" to "bottom up" work (Schore, 2021a). In this manner the developmentally dysregulated emotional and relational stressors in a therapeutic reenactment of dissociated affects associated with early relational attachment trauma can be re-experienced, communicated, come into consciousness, shared, and regulated.

In recent writings in relational psychoanalysis Aron and Bushra (1998) have used the construct of regression to describe a particular "loosening of structure" in which the clinician "is not seen as remaining in a 'normal,' 'rational' state holding the patient who regresses to a primitive or childish state," but rather a "mutual regression" in which both move "through a wide range of states, each mutually regulating the other's experience as the process unfolds. For this process to work, patient and analyst must differentially surrender to one another and become transformed" (p. 408, italics added). Aron and Atlas (2015) now assert, "Just as we may 'get stuck' in enactments, unable to work our way out of them so to we may inhibit or avoid entering into or surrendering to therapeutically generative enactments" (p. 322). Indeed, mutual regressions into regulated therapeutic enactments provide a growth-promoting context 
that over time can transform an insecure into a secure attachment pattern.

Overall, the clinical interpersonal neurobiological therapeutic principle of working with mutual regressions and relational trauma in a mutual enactment and indeed with any disturbance of affect regulation dictates that the psychobiologically attuned empathic therapist facilitates the patient reexperiencing overwhelming affects in incrementally titrated, increasing affectively tolerable doses in the context of a safe and trusting environment, so that overwhelming traumatic feelings can be regulated, come into consciousness, and be adaptively integrated into the patient's emotional life. In this manner, adaptive, interactively regulated mutual regressions within synchronized reenactments "generate interpersonal as well as internal processes eventually capable of promoting integration and growth" (Ginot, 2007, p. 317), including the growth of the patient's right brain unconscious self image.

Furthermore, in very recent work I have offered a contribution on the interpersonal neurobiology of intersubjectivity (Schore, 2021b), an unconscious nonverbal communication between the infant's and mother's mind that emerges in the second month of life. Here I discuss the early and enduring adaptive origins of mutual play in psychotherapy, including the imaginative games of child psychotherapy. In that work I offer recent scientific and clinical evidence documenting that the early appearing right brain-to-right brain intersubjective maternal-infant protoconversation that appears in the first few months of life represents the foundation of an imaginative and resonant playful sharing of our inner subjectivity with another subjective self. My colleague Russel Meares (2016) argues that in optimal developmental contexts, the right brain-to-right brain nonverbal protoconversation continues in the second year, a time when a toddler develops a burgeoning playful imagination and shows an expanded need for novel experiences. This earliest form of symbolic play allows the toddler to play with ideas and generate fantasies, including fantasied interactions with other minds. Furthering these ideas I would add that upon entering early childhood these products of the emergent imagination can also be shared with a valued other in the intersubjective play of creative storytelling.

This interpersonal neurobiological model applies to mutual regressions in the imaginative games of all forms of integrative play therapy (Drewes, Bratton, \& Schaefer, 2011), including sandtray therapy. Homeyer \& Sweeney (2010) define sandtray therapy as "an expressive and projective mode of psychotherapy involving the unfolding and processing of intra-and interpersonal issues through the use of specific sandtray materials as a nonverbal medium of 
Journal of Symbols \& Sandplay Therapy, Vol.12 No.2.

communication, led by the client(s) and facilitated by a trained therapist" (p. 4). In 2004 I met with Sachiko Taki-Reece here in Los Angeles, where she introduced me to sandplay. In her subsequent writings on this she describes sandplay as a nonverbal psychotherapy "evoking imagination, and the treasures of the imaginal realm, and all in the context of loving attention." Incorporating my work she emphasizes "the relational aspect of sandplay" where the therapist, acting "intuitively," "without interpretation," provides "a safe space and a client will play freely in that space." This shared space includes "more and more symbolic expression." She observes "a nonconscious sense of safety recreated $\cdots$ by the therapist; the therapist's non-verbal behavior, by the therapist's tone of voice, by her resonance with him and also by her not being in front of him but behind him. The sandplay therapist is non-directive, just more or less following him."

In astute clinical observations Taki-Reece (2004) described the sandplay therapist's skills that "include how to form resonance to sense of connectivity with the child and how to be responsive to the child." In this context of a "two person psychology," "the therapist's timing is right on, in synchrony," and the "patient feels the background presence of the therapist," and is open to "surprise." She states that relational sandplay therapy accesses a co-created "joint therapeutic alliance" "on a nonverbal level" that in turn allows for a rapid therapeutic access to a "right hemispheric representation" of child's inner world. In this therapeutic interaction the child is accompanied by "the background presence *o of someone trustworthy in his world." This relational context of "interactive regulation" allows for "a background regulatory presence," in which child experiences "a continuity of being together with his imagination" which facilitates change by acting as "growth facilitating environment." I'd add that from the neuropsychoanalytic perspective of regulation theory this "right hemispheric representation" is jointly entered into by a synchronized mutual regression.

In very recent work my colleague Madeline De Little offers "Using the sand tray in the context of the latest research in neuroscience to transform clients' defences" (2020), where she incorporates my work and others in interpersonal neurobiology. She describes how right brain-to-right brain "collaborative" attachment communications in which "the implicit self of therapist interacts with implicit self of patient," allow for increasing safety and trust in the therapeutic relationship, and how the "the use of play, imagination, and creativity using figurines in the sand tray transforms the client's defences" (p. 263). Her sand tray approach is centered 
in the therapeutic relationship of nonverbal affective communication in which the "fully present" clinician's tracks moment-to-moment nonverbal changes in patient's body associated with defensive dissociation, and with choice and placement of figurines. These occur in therapeutic enactments and mutual regressions.

Citing sand tray case material she observes, "The client and the therapist attain a tacit agreement that the client is safe enough, that they are in the process together, and that they are going back and down into the unconscious to explore stored dissociated, impactful, and painful memories that have no words" (pp. 263-264). De Little's therapeutic approach to sand tray is thus directed towards transforming the dissociative defense by "eliciting the projective identification into figurines and the subsequent enactment (s) that bring about profound "aha" moments of transformation" (p. 259). Of special importance are the patient's affective responses to figurines, right hemispheric images and novel metaphors, unconventional, unfamiliar, unique images outside of conscious awareness. Regulation and symbolization of defensive patterns are associated with shifts of energy and integration within patient's brain. The author emphasizes that in the work, "The therapist stays in a state of mutual regression throughout the session and only comes out of this deeply connected sate to ask process questions of the sand tray and of the client's body" (p. 272)

Returning to the clinical applications of regulation theory, the clinical skills for working in and with an array of child and adult therapeutic relationships are enhanced right hemispheric implicit emotional and relational functions, including the adaptive capacity to empathically synchronize, receive, and express bodily-based nonverbal communications, the ability to sensitively register slight changes in child's emotional expressions, an immediate awareness of one's subjective and intersubjective experience, and the regulation of one's own and the patient's affect. These intuitive therapeutic skills improve with clinical experience. In earlier writings I concluded, "Psychotherapy, 'a relationship of care,' can alter more than the left-lateralized conscious mind; it also can influence the growth and development of the unconscious "right mind.' It is undoubtedly true that both brain hemispheres contribute to effective therapeutic treatment, but in light of the current relational trend that emphasizes 'the primacy of affect,' the right brain, the 'social,' 'emotional' brain is dominant in all forms of psychotherapy" (Schore, 1914, p. 395). This includes adult and child psychotherapy. 
Journal of Symbols \& Sandplay Therapy, Vol.12 No.2.

\section{References}

Aron. L., \& Atlas, G. (2015). Generative enactment: Memories from the future. Psychoanalytic Dialogues, 25, 309-324.

Aron, L., \& Bushra, A. (1998). Mutual regression: Altered states in the psychoanalytic situation. Journal of the American Psychoanalytic Association, 46, 389-412.

De Little, M. (2020). Using the sand tray in the context of the latest research in neuroscience to transform clients' defences. Canadian Journal of Counselling and Psychotherapy, 54, 259-285.

Drewes, A. A., Bratton, S. C., \& Schaefer, C. E. (2011). Integrative play therapy. Hoboken, NJ: John Wiley \& Sons.

Freud, S. (1923). The ego and the id. In J. Strachey (Ed. and Trans.), The standard edition of the complete psychological works of Sigmund Freud (Vol. 19, pps. 12-63). London: Hogarth Press.

Homeyer, L., \& Sweeney, D. (2010). Sandtray therapy: A practical manual (2 ${ }^{\text {nd }}$ ed.). NewYork: Routedge. Jung, C. (1912). Symbols of transformation. Collected works 5. Princeton, NJ: Princeton University Press.

Keenan, J. P., Rubio, J., Racioppi, C., Johnson, A., \& Barnacz, A. (2005). The right hemisphere and the dark side of consciousness. Cortex, 41, 695-704.

McGilchrist, I. (2015). Divine understanding and the divided brain. In J. Clausen \& N. Levy (Eds.), Handbook of neuroethics. Dordrecht, Netherlands: Springer Science. doi:10.1007/978- 94- 0074707-4_99

Meares, R. (2017). The disintegrative core of relational trauma and a way toward unity. In M. Solomon \& D. J. Siegel (Eds.), How people change: Relationships and neuroplasticity in psychotherapy (pp. 135-150). New York, NY: Norton.

Norcross, J. C. \& Lambert, M. J. (2018). Psychotherapy relationships that work III. Psychotherapy, 55, 303-315.

Schore, A. N. (1994). Affect regulation and the origin of the self: The neurobiology of emotional development. New York: Routledge.

Schore, A. N. (2001). The effects of relational trauma on right brain development, affect regulation, and infant mental health. Infant Mental Health Journal, 22, 201-269.

Schore, A. N. (2003a). Affect dysregulation and disorders of the self. New York: Norton

Schore, A. N. (2003b). Affect regulation and the repair of the self. New York: Norton.

Schore, A. N. (2014). The right brain is dominant in psychotherapy. Psychotherapy, 51, 388-397.

Schore, A. N. (2019a). Right brain psychotherapy. New York: Norton. 
Allan Schore / Right Brain-to-Right Brain Psychotherapy: Recent Clinical and Scientific Advances

Schore, A. N. (2019b). The development of the unconscious mind. New York: Norton.

Schore, A. N. (2021a). The interpersonal neurobiology of therapeutic mutual regressions. In Interpersonal neurobiology and clinical practice, eds. D. J. Siegel, A. N. Schore, \& L. Cozolino. pp. 27-58. New York: Norton.

Schore, A. N. (2021b). The interpersonal neurobiology of intersubjectivity. Front. Psychol. 12: 648616. doi: 10.338

Schore, J. R., \& Schore, A. N. (2008). Modern attachment theory: The central role of affect regulation in development and treatment. Clinical Social Work Journal, 36, 9-20.

Zhang, Y., Meng, T., Hou, Y., Pan, Y., \& Hu, Y. (2018). Interpersonal brain synchronization associated with working alliance during psychological counseling. Psychiatry Research Neuroimaging, 282, 103-109.

Zhang, Y., Meng, T., Yang, Y., and Hu, Y. (2020). Experience-dependent counselor-client brain synchronization during psychological counseling. eNeuro 236, 1-10. doi:

10.1532/ENEURO.0236-20.2020 
상징과모래놀이치료, 제 12 권 제 2 호

Journal of Symbols \& Sandplay Therapy

2021, 12, Vol. 12, No. 2, 13-22.

doi https://doi.org/10.12964/jsst.21007

\title{
우뇌에서 우뇌로의 심리치료* \\ Right Brain-to-Right Brain Psychotherapy: \\ 최신 임상 및 연구진전을 반영함
}

\author{
Allan Schore ${ }^{* *}$
}

정신건강 분야는 현재 최신의 임상치료모형과 신경과학의 통합에서 주로 기인하는 패러 다임의 변화를 경험하고 있다고 주장한다(Schore, 2003b, 2012, 2019a 참조). 전체적으로 신경 과학은 기술진보 및 과학적 임상훈련으로 기술을 확장시켜 나가고 있는 두 가지 이유로 인 해 빠르게 성장하고 있다. 이러한 확장은 19세기 현대 신경학의 태동과 함께 처음 시작된 대뇌 측두화의 발견 그리고 우뇌와 좌뇌 즉 무의식적 정신과 의식적 정신의 서로 다른 구 조적, 기능적 조직화의 발견에 의해 가속화되고 있다. 나의 연구의 임상 및 이론 모형은 우 뇌와 우뇌의 신체 중심의 정서, 관계, 생존 촉진적 과정에 대한 지속적인 연구작업을 보여 준다.

양방향성을 가진 이 자기시스템의 기원에 관해 대부분의 연구결과들은 언어중심의 좌뇌 보다 정서와 이미지 중심의 우뇌성숙이 먼저 이루어진다는 것을 보여준다. 임상연구와 신 경정신분석 연구결과들은 무의식적 정신이 의식적 정신 보다 먼저 발달하며, "그림으로 사 고하는 것이 $\cdots$ 언어로 사고하는 것 보다 무의식과정에 훨씬 더 가까울 뿐 아니라 개체발생 학적 발달 및 계통발생학적 발달 보다 한참 전에 이루어진다"는 Sigmund Freud(1923)의 오래 된 공식을 지지한다(p. 21). 이러한 개념화와 일치하게, 신경정신의학자인 Iain McGilchrist (2015)는 두 대뇌반구의 기능분화에 대한 독특하고 광범위한 연구를 통해 우반구는 우리의 경험을 현실에 근거하게 하고 다른 한 편으로는 그것의 의미를 만든다는" 것, 우반구는 정

* 본 특별기고 논문은 2021년 11 월 27일 한국임상모래놀이치료학회 학술대회 발표자료를 중심으로 기술 되었음.

** UCLA 데이비드 게펜 의과대학 
Journal of Symbols \& Sandplay Therapy, Vol.12 No.2.

서 및 신체와 더 접촉한다는 것, 그리고 “신경학 연구결과들도 정서우선성 및 의식적 의지 에 대한 무의식적 의지의 우선성 개념과 일치한다"는 것을 주장했다(p. 44).

지난 30년 동안 나는 우뇌가 인간무의식의 심리생물학적 층이라는 것을 보여주는 학제간 연구 및 임상자료들을 제시해왔다. 우뇌편향화 된 주관적 자기(self)의 깊은 핵심은 생애 초 기 모-유아 애착에서 발달하며, 전 생애에 걸쳐 이 역동적 체계는 의식적 인식 아래 수준에 서 상호주관적으로 다른 우뇌에게 소통하고 다른 우뇌의 소통내용을 받아들인다. 이 비언 어적 의사소통체계는 암묵적인(무의식적인) 의사소통의 상호조절 그리고 그에 따른 유기체 간 그리고 유기체 내에서의 생물학적 주관성의 조절로 표현되는 진화론적 애착기제의 기초 다(Schore, 2003a). 따라서 동시화된(synchronized) 우뇌-우뇌의 정서로 충만한 애착역동은 내면 의 항상성 상태를 공동으로 조절하기 위해 인간이 타인들과 사회생리학적으로 연결되는 생 물심리사회적 기제로 작용한다(Schore, 2003a).

이 모-유아 2 인 관계의 발달모델을 임상맥락에 적용하여 나는 공동창조된 심리치료관계 가 치료동맹의 발달에서 정서상태를 신속하게 의사소통하는 역동적인 상호주관적 맥락으로 어떻게 작용하는지 기술했다. 두 우뇌 사이에서 자발적으로 일어나는, 자기상태에 관한 비 언어적 소통은 1 초 또는 2-3초의 시간 틀이라는 현재 순간에 발생한다. 중요한 것은 이 "관 계무의식”이 다른 관계무의식과 소통할 뿐 아니라 서로 동시화 되고 확장 된다는 것이다 (Schore, 2019a, b; 2020a, b). 이렇게 동시화된 우뇌패턴의 커플링은 치료의 쌍(치료자-내담자) 이 무의식적인 암묵적 의사소통의 정서 및 조절 기능을 서로 공유할 수 있게 하여 내담자 의 우뇌의 심리치료적 성장과 발달을 촉진한다.

두 권의 최신 저서인 「우뇌심리치료Right Brain Psychotherapy」와「무의식적 정신의 발 달Development of Unconscious Mind」에서 조절이론, 발달이론, 정신병인론 및 주관적 자기의 치료에 대한 이론 및 임상연구를 더욱 확장기술하였다. 이 대인관계 신경정신분석 모델은 심리치료의 과정 차원인 드러나있는지 않은 본질적인 상호주관적 맥락을 설명한다. 이를 위해 나는 대인관계 신경생물학 분야의 최근 발견이 모든 형태의 심리치료에서 치료작용의 기본 원리에 대해 더욱 심화된 이해와 직접적으로 관련이 있음을 보여주는 과학 및 임상 데이터를 모두 제시하였다(Schore, 2019a, b). 이 두 저서에서 나는 내담자와 치료자의 언어 아래에서 작용하고 있는 자발적이고도 무의식적으로 그리고 빠르게 발생하는 우뇌-우뇌 의 사소통과 암묵적인 상호주관적 관계과정에 내재되어 있는 비언어적이고 조절적인 의사소통 의 대인관계기능을 설명하였다. 초기 애착역동의 재연(encatment)과, 정서적으로 고조된 치료 순간의 상호퇴행의 성장촉진 효과에 특별히 초점을 맞추었다. 광범위한 임상자료를 인용하 여 심리치료에서의 재연과 상호퇴행이 무의식적 정신에 깊이 숨겨져 있는 본질적 기능에 초점을 맞출 것을 제안하였다. 이것이 인간경험의 모든 측면에 중심적으로 관여하는 것임 을 Freud가 입증한 것과 같다, 
이 “2인”관계 신경생물학 모델은 성인, 아동, 부부 및 집단심리치료를 포함한 모든 형태 의 심리치료에서 주요한 변화원리로서 우뇌의 지속적인 신경가소성 발달을 강조한다. Psychotherapy저널의 Evidence-based Psychotherapy relationship이라는 제목의 특별호 논문에서 에 디터인 Norcross와 Lambert(2018)는 다음과 같이 기술했다. "수십 년간의 연구증거와 임상경 험 모음: 심리치료 관계는 치료와 무관하게 결과에 실질적이고 일관된 기여를 한다."(p. 313 이탤릭체는 인용하면서 추가한 것임). 나는 또한 임상가와 내담자가 공동으로 구축한 치료 관계에서 두 개의 우뇌시스템의 상호작용에 대한 더 깊은 이해를 제공하기 위해 최신의 신 경과학방법 및 기술발전에 관한 정보를 제공하였다. 1994년에 처음 제안된 우뇌에서 우뇌 로의 모델은 이제 내담자와 치료자의 상호작용하는 두 뇌에 대한 획기적인 패러다임 전환 을 가져온 하이퍼스캐닝 연구결과로 지지되며, 이 연구결과들은 정서적으로 몰입되어 있는 심리치료에서 두 사람의 뇌 사이에서 일어나는 우뇌편향적 동시화를 보여준다(Zhang et al., 2018, 2020). 이러한 발전은 의식적 자각 아래 수준에서 치료의 두 구성원 사이에 작동하는 암묵적인 관계과정을 더 깊이 이해할 수 있는 귀중한 기회를 제공한다.

공동창조된 내담자-치료자 관계에 내재되어 있는 감정소통의 “숨겨진" 무의식적, 비언어 적 애착유대와 관련하여 나의 연구는 어떻게 내담자와 공감적인 치료자 사이의 빠르게 역 동적으로 변화하는 순간순간의 상태공유가 조직화된 대화, 천분의 일초 단위로 발생하는 비언어적 대화전환을 가져오는지를 설명해준다. 이 상호작용 매트릭스에서 두 사람은 자발 적으로 자신의 상태를 상대방에게 서로 일치시킨 다음 상대방의 신호에 대한 응답으로 자 신의 사회적 관심, 자극, 주관적 각성을 상대방에게 맞추어 동시에 조정한다(Schore, 2003b). 각자의 의식적 마음상태 특히 무의식적 마음상태를 상대방에게 암묵적으로 알릴 수 있는 것은 이러한 우뇌와 우뇌의 상태공유 때문이다(Schore, 2019a,b; 2021a,b).

보다 구체적으로 말하면, 의식적 자각 아래의 수준에서 심리생물학적으로 조정된 직관적 인 치료자는 첫 번째 접촉지점에서 내담자의 내부상태의 비언어적인 순간순간의 리듬 구조 를 배우며 이 구조와 동시화면서 치료동맹이 조직화 맥락을 공동창조해내도록 하기 위해 상대적으로 유연하고 유동적으로 자신의 행동을 수정한다. 이 우뇌로 편측화된 두 뇌의 동 시화는 우뇌에서 우뇌소통체계의 2 인관계의 출현을 허용한다. 신경과학연구자들은 이제 “두 반구 사이의 역동적 상호작용이라고 생각할 수 있는 치료적 대화의 한 형태”(Meares, 2017) 를 기술하고 있으며 “우반구는 실제로 자신의 정신상태 즉 자신의 뇌 뿐 아니라 다른 사람 의 뇌(그리고 정신)을 해석한다고 주장한다. 자신의 뇌 뿐 아니라 다른 사람들의 뇌(그리고 마음)"(Keenan et al., 2005, p. 702).

그러한 비의식적인 순간순간의 신체기반 의사소통에서 민감하고 직관적인 치료자는 내담 자와 자신 모두에서 "상태변화를 나타내는 거의 인지할 수 없는 단서"에 주관적으로 주의 를 기울일 수 있으며 내담자의 “비언어적 행동과 정서변화를 상호주관적으로 감지할 수 있 
Journal of Symbols \& Sandplay Therapy, Vol.12 No.2.

다." 이러한 우뇌의 상태공유는 치료적으로 함께함의 상태에 있는 치료자가 "정서를 따르 고”(Schore, 1994) 내담자의 정서를 조절하는 암묵적인 정서조절자의 역할을 하기 위해 내담 자의 변화하는 감정상태에 들어가게 한다. 심리치료적으로 동시화되어 상호조절되는 우뇌 편향적 소통은 내담자의 우뇌 조절시스템의 신경가소성 구조변화를 촉진하기 때문에 증상 감소 심리치료와 성장촉진 심리치료 모두에서 최적의 치료 결과를 얻게 한다.

나는 계속해서 학대 및 방임과 관련된 혼란애착의 생애사를 포함하여 생애 초기의 안정 및 불안정애착 뿐 아니라 안정애착의 역동을 설명하였다. 신경정신분석학적 관점을 활용하 여 조절된 애착역동과 조절되지 않은 애착역동, 스트레스가 많은 전이-역전이 관계, 암묵적, 상호작용적 정서조절에서 작용하는 우뇌의 암묵적인 신경생물학적 메커니즘에 대해 설명하 였다. 1994, 2003b, 2012, 2019a). 특히 내가 발달과정에서의 “관계외상"(Schore, 2001)이라고 명명한 것이 미치는 지속적인 부정적 영향은 우뇌로 측두화된 주관적 자기가 다른 정신과 의사소통하는 능력, 즉 상호주관성과 애착형성을 위한 상호작용적 정서조절에 초점을 맞춘 것이다. 이 관계외상은 해리방어를 둔화시키는 정서와 관련된다.

이 과정에서 의식적 특히 무의식적 조절곤란 경험은 내담자와 치료자 사이에 천분의 일 초 단위로 공동창조된 정서적 애착유대 안에서 우뇌에서 우뇌로 소통된다. 특히 스트레스 적이고 조절되지 않은 주관적 정서상태 안팎으로 정서가 변화하는 순간에 그러하다. 치료 동맹에 내재되어 있는 정서유대의 이러한 전이적이고 관계적인 스트레스 요인은 치료의 중 심적 관계원리인 2 인관계 파열 및 회복 교류에서 필수 요소다. 파열-회복에서 이러한 정서 교류는 두 사람의 우뇌 사이에서 우뇌-우뇌로의 정서유대를 재구축 하면서 관계적으로 동 시화되고 상호작용적으로 조절될 수 있다. 시간이 지남에 따라 이 관계적이고 정서적인 의 사소통 시스템은 발달하고 있는 치료관계의 안전과 신뢰수준을 증가시키고 그에 따라 생애 초기 발달스트레스 관련 애착역동의 재연을 공동으로 처리할 수 있게 한다.

애착기제, 초기 발달외상로 인해 스트레스가 많은 전이-역전이 의사소통, 임상에서의 애 착유대의 파열 외에도 치료자-내담자의 상호퇴행이라는 임상 구성요소는 심리치료, 특히 정 신역동적 심리치료에서 정서성장과 발달을 촉진하는 핵심기제로 작용한다. 이것을 성취하 기 위해서는 반구지배성을 치료자의 좌뇌에서 우뇌 즉 내담자의 정서적 스트레스와 고통스 런 자전적 애착기억 저장고로 옮기는 기제가 필요하다. 신경과학은 퇴행을 “더 높은 곳으로 부터 벗어나는 것” 그리고 “동시에 내려놓는 것 또는 더 낮은 것에 대한 표현”으로 오랫동 안 정의해왔다(Schore, 2019a). 이렇게 상호퇴행이라는 즉각적인 동시화상태로의 이동은 치료 의 2 인관계를 “위->아래"로부터 “아래->위”의 작업으로 가게한다(Schore, 2021a). 이런 식으 로 생애초기 관계애착외상으로 인한 해리된 정서가 치료에서 재연될 때 발달과정에서 조절 되지 않았던 정서 및 관계 스트레스가 의식되고, 공유되며, 조절된다. 신경정신분석학적 조 망에서는 왼쪽의 “높은" 좌반구에서 오른쪽의 “낮은" 우반구로의 퇴행기제 속도가 빨라서 
무의식적 수준에서 작용하는 대뇌방향성의 일시적 이동을 의미한다(Schore, 2019a, 2021a). 이 렇게 공감적인 치료자의 우뇌는 내담자 우뇌의 의식적, 무의식적 초기 애착소통을 받아들 이고 반응할 수 있다. 지난 세기 초 Carl Jung(1912)은 “자기와의 접촉을 상실한, 무의식적 마음에 숨겨진 자기(the self)의 중요한 생성적 핵심과 접촉하도록 하기 위해 생애 초기 단계 로 되돌아가는 “환자의 치료적 퇴행”의 중요성에 대해 기술했다. "그는 치료는 퇴행을 지 지해야 하며 지지는 ‘출생 전' 단계에 도달할 때까지 지속되어야 한다. . . 따라서 퇴행은 분 명히 어머니에게 되돌아가는 것이다. . . 그러나 어머니의 영역을 넘어서 출생 전 영역 즉 전체성의 씨앗상태로 되돌아간다. . . 궁극적이지만 무의식적인 퇴행을 가능하게 하는 것은 ‘영적' 또는 '상징적' 삶과 발달의 고유한 가능성이다." (paragraphs 508-510).

현재의 2 인 관계모델은 퇴행의 구성요소는 한 사람의 뇌에서 일어나는 정신내적 (intrapsychic) 퇴행으로부터 상호작용하는 두 사람의 뇌가 공유하는 관계적 상호퇴행(mutual regression)으로 옮겨가고 있다. 이런 식으로 내담자-치료자라는 치료적 2 인관계는 나중에 발 달하게 되는 “상위” 좌반구의 언어 및 인지 기능으로부터 내담자와 치료자 모두의 뇌량의 가역적 우세를 가져올 수 있는 즉 생애초기에 발달하는 “하위” 우반구의 비언어적, 사회-정 서적 기능 즉 대인관계의 동시화기제에 접근할 수 있게 된다. 상호 퇴행의 이 자발적인 동 시화 상태로의 변화는 치료적 2인관계가 “위->아래"에서 “아래->위”로의 작업전환을 할 수 있게 한다(Schore, 2021a). 이러한 방식으로, 초기 관계애착 트라우마와 관련된 해리된 정서 가 치료상황에서 재연될 때 발달적으로 조절되지 않는 정서 및 관계스트레스 요인이 재경 험되고, 전달되고, 의식에 이르고, 공유되고, 조절될 수 있다.

관계정신분석학 분야의 최근 저술에서 Aron과 Bushra(1998)는 임상전문가가 원시적이거나 어린아이 같은 상태로 퇴행하는 내담자를 담아주고 있는 '정상적, '합리적' 상태에 있는 것 이 아니라 광범위한 상태를 통해 두 사람이 함께 변화하는 즉 과정의 진행에 따라 상대방 의 경험을 서로 조절하는 "구조의 느슨해짐(loosening of structure)"을 기술하기 위해 상호퇴 행(mutual regression)"을 사용하였다. 이 과정이 작동하려면 내담자와 분석가가 서로에게 순 복하고 변화되어야 한다"(p. 408, 인용하면서 이탤릭체 추가). Aron과 Atlas(2015)는 이제 “재 연에 갇혀 앞으로 나아갈 수 없는 것처럼 우리는 치료적으로 만들어진 재연에 들어가거나 굴복하는 것을 억제하거나 피할 수 있다.”라고 주장한다(p. 322). 실제로, 조절되고 있는 치 료재연을 통해 작용하는 상호퇴행은 시간이 지남에 따라 불안정한 애착패턴을 안정 애착패 턴으로 변화시킬 수 있는 성장촉진 맥락을 제공한다.

전반적으로, 상호 재연에서의 상호퇴행과 관계외상 및 정서조절 혼란을 작업하는 임상대 인 신경생물학적(clinical interpersonal neurobiological) 치료원칙은 정신생물학적으로 조율된 공 감적 치료자가 안전하고 신뢰로운 환경 안에서 내담자가 점진적, 정서적으로 견딜 수 있는 적절한 강도를 증가시키면서 정서를 재경험할 수 있도록 하여 압도적인 외상감정이 조절되 
Journal of Symbols \& Sandplay Therapy, Vol.12 No.2.

고 의식화되며 내담자의 정서적 삶에 적응적으로 통합되도록 촉진한다는 것이다. 이러한 방식으로 동시적으로 일어나는 재연 안에서의 적응적이고 상호조절된 상호퇴행은 내담자의 우뇌의 무의식적 자기이미지의 성장을 포함하여 “궁극적으로 통합과 성장을 가능하게 하는 내적이면서 동시에 대인관계적인 과정을 생성”한다(Ginot, 2007, p. 317).

더 나아가, 나는 매우 최근 연구에서 상호주관성의 대인관계 신경생물학(Schore, 2021b), 즉 생후 두 번째 달에 출현하는 유아와 어머니의 마음 사이의 무의식적인 비언어적 의사소 통에 관해 기술 했다. 여기에서 나는 아동심리치료의 상상게임을 포함하여 심리치료에서 상호 놀이의 초기 및 초기 이후의 지속적인 적응기원에 대해 논의하였다. 이 논의에서 나 는 생후 첫 몇 달 동안 나타나는 생애초기 우뇌에서 우뇌로의 상호주관적 모-유아 원시대 화(protoconversation)가 우리 내면의 주관성을 다른 사람의 주관적 자기와 상상으로 공유하는 것 그리고 실제로 공명적인 즐거운(playful) 공유를 이루는 것의 기초를 보여주는 최근의 과 학 및 임상 증거를 제시했다. 나의 동료 Russel Meares(2016)는 최적의 발달상황에서 우뇌에 서 우뇌로의 비언어적 원시대화는 유아가 막 싹트기 시작한 즐거운(playful) 상상력을 발달 시키고 새로운 경험에 확장하고 싶은 욕구를 보여주는 생후 2년차에도 계속된다고 주장한 다. 이 가장 초기 형태의 상징놀이를 통해 유아는 생각을 놀이하고 다른 사람의 마음과의 환타지적 상호작용을 포함하는 환타지를 만들어낼 수 있다. 이러한 생각을 더 발전시켜 나 는 아동기에 들어가면 이렇게 출현하는 상상력의 산물을 창조적인 스토리가 있는 상호주관 적 놀이를 통해 중요한 타인과 공유할 수 있게 된다는 것을 덧붙이고 싶다.

이 대인관계 신경생물학 모델은 모래놀이치료를 포함하는 모든 형태의 통합적 놀이치 료의 상상게임에서의 상호퇴행에 적용된다(Drewes, Bratton, \& Schaefer, 2011). Homeyer와 Sweeney(2010)는 모래놀이치료를 "내담자가 이끌고 훈련받은 치료자가 촉진하는 비언어적 의 사소통 매체로서, 특정 모래놀이재료의 사용을 통해 개인내적 및 대인관계적 이슈를 표현 하고 처리하는 표현적이고 투사적인 방법(p. 4)"으로 정의했다. 2004년 나는 이곳 로스앤젤 레스에서 Sachiko Taki-Reece를 만났고 그곳에서 그녀는 나에게 모래놀이치료를 소개해 주었 다. 이 만남에 관한 이후의 저술에서 그녀는 모래놀이치료를 “상상, 상상 영역의 보물 그리 고 사랑스런 주의가 주어지는 맥락에서 모든 것을 자극하는” 비언어적 심리치료로 기술했 다. 그녀는 나의 작업을 통합하여 "직관적으로" 행동하는 치료자가 “해석없이" "안전한 공간 을 제공하고 내담자는 이 공간에서 자유롭게 놀이하는” 모래놀이치료의 관계적 측면을 강 조했다. 이 공유된 공간은 “점점 더 많은 상징적 표현”을 포함하게 된다. 그녀는 “...치료자 에 의해 재창조된 무의식적 안전감을 관찰할 수 있었으며 치료자의 비언어적 행동 즉 치료 자의 목소리 톤, 내담자에 대한 치료의 공명, 그리고 또한 치료자가 내담자 앞에 있지 않고 내담자 뒤에 있다는 것에 의해 무의식적인 안전감이 생겨나는 것을 관찰할 수 있었다. 모 래놀이치료자는 지시적이지 않으며 그저 내담자를 따를 뿐이다.” 
예리한 임상관찰에서 Taki-Reece(2004)는 "아동과의 연결되었음을 공명하는 방법 그리고 아동에 반응하는 방법을 포함하는 모래놀이치료자의 기술"에 관해 묘사했다. 이러한 "2인 심리학”의 맥락에서, “치료자의 타이밍은 적절하고 동시적”이며 “내담자는 치료자의 배경존 재를 느끼게 되고" “놀라움”에 개방적일 수 있게 된다. 그녀는 관계적 모래놀이치료가 “비 언어적 수준에서" 공동창조된 “공동의 치료동맹”을 이룰 수 있게 하며 이는 아동의 내면세 계의 “우반구 표상”에 신속하게 치료적 접근이 이루어질 수 있게 한다고 언급했다. 이 치료 적 상호작용에서 아동은 “자신의 세계에서 신뢰할 수 있는 누군가의 배경존재..."와 함께 한 다. "상호작용적 조절”이라는 이 관계맥락은 아동이 상상을 통해 함께함의 지속을 경험하는 “조절적 배경존재”를 갖게 하며 이는 성장촉진적 환경으로 작용함으로써 변화를 촉진한다. 나는 조절이론에 관한 신경정신분석학적 관점에서 이 “우반구 표상”이 동시화된 상호퇴행 에 의해 공동으로 가능하게 된다는 것을 덧붙이고자 한다.

매우 최근의 작업에서 나의 동료인 Madeline De Little은 "최신 신경과학연구에서 내담자의 방어를 변화시키기 위해 모래놀이치료를 활용할 것”(2020)을 제안했으며 여기에서 그녀는 나의 연구와 대인관계 신경생물학 분야의 다른 사람들의 연구를 통합기술했다. 그녀는 “치 료자의 암묵적 자기가 내담자의 암묵적 자기와 상호작용하는” 우뇌에서 우뇌로의 “협동적" 애착의사소통이 치료관계에서 안전과 신뢰를 높이는 방법 그리고 "모래상자에 피규어를 사 용하는 놀이, 상상, 창조성의 사용"이 내담자의 방어를 변화시키는 방법”에 관해 기술했 다"(p. 263). 그녀의 모래놀이치료 접근방식은 “온전히 존재하는” 치료자가 방어적 해리, 피 규어 선택 및 배치와 관련된 내담자 신체의 순간순간 비언어적 변화를 추적하는 비언어적, 정서적 의사소통의 치료관계에 중점을 둔다. 이는 치료적 재연과 상호퇴행에서 발생한다.

그녀는 모래놀이치료 사례자료를 인용하면서 이 사례자료에서 "내담자와 치료자는 내담 자가 충분히 안전하고, 그들이 함께 과정을 거치고 있으며, 해리된 충격적이고 말로 표현될 수 없는 고통스러운 기억을 탐색하기 위해 무의식으로 돌아올 것이라는 무언의 동의를 한 다"는 것을 관찰했다(pp. 263-264). 따라서 모래놀이치료에 대한 De Little의 치료접근은 “피 규어에 투사적 동일시를 하는 것 그리고 '아하'의 변화순간을 가져오는 이후의 재연에 의한 해리방어의 변화에 초점이 맞추어져 있다"(p. 259). 나는 내담자의 정서로 가득찬 피겨에의 투사가 Traevarthen이 " 2 차적 상호주관성(secondary intersubjectivity)라고 부른 몸짓 및 시선응시 와 함께 이루어진다는 점을 언급하고자 한다. 우뇌적 또는 공동의 주의(shared attention)에 대해 무의식적으로 이루어지는 이 사회적 상호참조 반응은 내담자와 치료자의 우뇌 하전두 엽이랑(interior frontal gyrus)의 동시화(synchronization)의 표현이다(Koike et al., 2016). De Little은 피규어 즉 비관습적이고 친숙하지 않고 독특하며 또한 의식적 인식 밖에 있는 우반구이미 지와 새로운 은유에 대한 내담자의 정서적 반응을 중요시한다. 패턴의 조절과 상징화는 내 담자의 뇌 안에서 에너지이동 및 통합과 관련되어 있다. 이 연구자는 자신의 저술에서 “치 
Journal of Symbols \& Sandplay Therapy, Vol.12 No.2.

료자는 세션 내내 상호퇴행 상태에 머물며 모래상자 장면과 내담자의 몸에 대한 과정질문 을 던질 때만 이 깊이 연결된 상태에서 빠져나온다"(p. 272)고 강조한다.

조절이론의 임상적용으로 돌아가도록 하겠다. 아동 및 성인과의 치료관계의 배열 안팎에 서 작업하는데 필요한 임상기술은 신체중심의 비언어적 의사소통을 공감적으로 동시화하 고, 수용하고, 표현하기 위한 적응능력, 아동의 정서표현의 미묘한 변화를 민감하게 알아채 는 능역 즉 주관적 및 상호주관적 경험에 대한 즉각적 인식, 그리고 치료자 자신과 내담자 의 정서를 조절하는 능력을 포함하는 증진된 우반구의 암묵적, 정서적, 관계적 기능이다 (Schore, 1914, p. 395). 이러한 직관적인 치료기술은 임상경험과 함께 개선된다. 이전 기술들 에서 나는 “심리치료 즉 '돌봄의 관계'가 좌뇌편향의 의식적 마음보다 더 많은 것을 바꿀 수 있다고 결론을 내린 바 있다. 그것은 무의식의 '올바른 마음'의 성장과 발달에도 영향을 미칠 수 있다. 좌우 두 반구 모두가 효과적인 치료에 기여하는 것은 의심할 여지가 없지만 '정서의 우위성'을 강조하는 현재의 관계경향에 비추어 볼 때 우뇌 즉 '사회적,' '정서적 뇌 는 모든 형태의 심리치료에서 지배적이다"(Schore, 1914, p. 395). 이는 성인 및 아동 심리치 료 모두에 해당된다. 


\section{References}

Aron. L., \& Atlas, G. (2015). Generative enactment: Memories from the future. Psychoanalytic Dialogues, 25, 309-324.

Aron, L., \& Bushra, A. (1998). Mutual regression: Altered states in the psychoanalytic situation. Journal of the American Psychoanalytic Association, 46, 389-412.

De Little, M. (2020). Using the sand tray in the context of the latest research in neuroscience to transform clients' defences. Canadian Journal of Counselling and Psychotherapy, 54, 259-285.

Drewes, A.A., Bratton, S.C., \& Schaefer, C. E. (2011). Integrative play therapy. Hoboken, NJ: John Wiley \& Sons.

Freud, S. (1923). The ego and the id. In J. Strachey (Ed. and Trans.), The standard edition of the complete psychological works of Sigmund Freud (Vol. 19, pps. 12-63). London: Hogarth Press.

Homeyer, L., \& Sweeney, D/ (2010). Sandtray therapy: A practical manual ( $2^{\text {nd }}$ ed.).NewYork:Routedge.

Jung, C. (1912). Symbols of transformation. Collected works 5. Princeton, NJ: Princeton University Press.

Keenan, J. P., Rubio, J., Racioppi, C., Johnson, A., \& Barnacz, A. (2005). The right hemisphere and the dark side of consciousness. Cortex, 41, $695-704$.

Koike, T., Tanabe, H.C., Okazaki, S., Nakagawa, E., Sasaki, A.T. Shimada, K. et al. (2016). Neural substrates of shared attention as social memory: A hypscanning functional magnetic resonance imaging study. NeuroImage, 125, 401-412.

McGilchrist, I. (2015). Divine understanding and the divided brain. In J. Clausen \& N. Levy (Eds.), Handbook of neuroethics. Dordrecht, Netherlands: Springer Science. doi:10.1007/978- 94- 0074707-4_99

Meares, R. (2017). The disintegrative core of relational trauma and a way toward unity. In M. Solomon \& D. J. Siegel (Eds.), How people change: Relationships and neuroplasticity in psychotherapy (pp. 135 - 150). New York, NY: Norton.

Norcross, J.C. \& Lambert, M.J. (2018). Psychotherapy relationships that work III. Psychotherapy, 55, 303-315.

Schore, A. N. (1994). Affect regulation and the origin of the self: The neurobiology of emotional development. New York: Routledge.

Schore, A. N. (2001). The effects of relational trauma on right brain development, affect regulation, 
Journal of Symbols \& Sandplay Therapy, Vol.12 No.2.

and infant mental health. Infant Mental Health Journal, 22, 201 - 269.

Schore, A. N. (2003a). Affect dysregulation and disorders of the self. New York: Norton

Schore, A. N. (2003b). Affect regulation and the repair of the self. New York: Norton.

Schore, A. N. (2014). The right brain is dominant in psychotherapy. Psychotherapy, 51, 388 - 397.

Schore, A. N. (2019a). Right brain psychotherapy. New York: Norton.

Schore, A. N. (2019b). The development of the unconscious mind. New York: Norton.

Schore, A. N. (2021a). The interpersonal neurobiology of therapeutic mutual regressions. In Interpersonal neurobiology and clinical practice, eds. D.J. Siegel, A.N. Schore, \& L. Cozolino, pp. 27-58. New York: Norton.

Schore, A. N. (2021b). The interpersonal neurobiology of intersubjectivity. Front. Psychol. 12:648616. doi: 10.338

Schore, J. R., \& Schore, A. N. (2008). Modern attachment theory: The central role of affect regulation in development and treatment. Clinical Social Work Journal, 36, 9-20.

Zhang, Y., Meng, T., Hou, Y., Pan, Y., \& Hu, Y. (2018). Interpersonal brain synchronization associated with working alliance during psychological counseling. Psychiatry Research Neuroimaging, 282, 103-109. 